PRODUCTION

ENGINEERING ARCHIVES
2015, Vol. 6, No 1, pp 10-13

ISSN 2353-5156 (print version)

ISSN 2353-7779 (online version)

\title{
The stapling of material layers process capability study by the production of the product "MULTIAXIAL"
}

\author{
Katarína Lestyánszka Škůrková
}

Slovak University of Technology in Bratislava, Faculty of Materials Science and Technology in Trnava, Institute of Safety, Environment and Quality, Botanická 49, 91724 Trnava, e-mail: katarina.skurkova@stuba.sk

\begin{abstract}
Ensuring the process capability currently means the warranty, that produced products will be in accordance with requirements from the company or customer's side. This study focuses on the statistics control of stapling of material layers process capability by production of the product "multiaxial". The stapling of material layers process is evaluated by control charts, specifically by control charts for average and range $(\bar{X}, \mathrm{R})$. As the results show, on the basis of the diagram for average and range we we are able to say that the process is under the statistical control. We had also finished the reguest for capability of process, where the indexes of capability process Cp and Cpk are higher than the determinated value by 1,33 points. The obtained values are: $\mathrm{Cp}=1,68 \mathrm{a} \mathrm{Cpk}=1,55$.
\end{abstract}

Keywords: process, stability, normality, capability, stapling

\section{Introduction}

The process capability means the process ability to permanently achieve defined quality criterions alongside the ability to work with some accuracy. The process capability evaluation is today often required by a customer because it is evidence that the product was made in stable production conditions where the required quality criterions were regularly ensured. This is also information about the accuracy which can he counted on in the future. For the producer it is very important information which enables him to choose a suitable machine for producing some products, estimate the risks of non conforming products creation and to plan the preventive and corrective actions for improvement. (HRUBEC J. 2009). The purpose of the statistical process control is to find, if every significant causes of process instability were removed. It is required that the mean value of the monitored quality character and its variability are constant in time. The best way to find this information is by using the Shewhart control charts and represent the preparatory stage of statistical regulation (HRUBEC J. 2001). The starting point for statistical regulation is to manage the production processes adequately. The production process is considered as well managed if it is affected by random causes only. If there is a large number of random causes in a process, the resulting distribution can be characterized as normal. Currently the process capability is evaluated by the process capability indexes $C_{p}$ (characterise the process dispersion) and $\mathrm{C}_{\mathrm{pk}}$ (characterise the process location in tolerance area). We can consider the process as capable, if the 
index values $C_{p}$ and $C_{p k}$ are higher than 1,33 point (HRUBEC J., VIRČÍKOVÁ E., 2009).

Between input data belong:

- production conditions of serial production

- capable measuring equipment

- capable production equipment

- process under statistical control

- normality consideration

- technical and other specification exactly expressing the customer's requirements

- the nominal value of the proposal in the middle of tolerance area.

Using this method it is necessary to take into account and to apply this information and findings from previous process observation (HRUBEC J. 2001).

The measured values are used for the calculation of:

Average value of attribute in subgroup:

$$
\overline{X_{i}}=\frac{1}{n} \sum_{j=1}^{n} X_{i j}
$$

for $\quad i=1,2 \ldots . k$ and for $j=1,2 \ldots n$,

where: $i$ - sequential number of subgroup,

$j$-sequential number of measured value in subgroup,

$k$ - number of subgroups,

$n$ - subgroup size,

$X_{i j}$ - measured value in $i$-th subgroup

Range in subgroup:

$$
R_{i}=\operatorname{MAX}\left(X_{i j}\right)-\operatorname{MIN}\left(X_{i j}\right)
$$

\section{Methodology of research}

\section{Process description:}

Working operation: the stapling of material layers

Character: multiaxiál width

Nominal value: $1,25^{ \pm 0,02} \mathrm{~m}$

Lower tolerance limit (LSL): 1,23 m

Upper tolerance limit (USL): 1,27 m

Number of measurements: $N=100$

Range of subgroups: $n=4$

Sampling interval: every 15 minutes

Number of subgroups: $k=25$

The observed organisation is situated in Western Slovakia and deals with the manufacturing of products for glass industry using the method "stapling of material layers". This article is focused on statistical evaluation of the stapling of material layers process by production of the product "multiaxiál" in connection with statistical regulation of the process. The criterions for capability evaluation are indexes $C_{p}$ a $C_{p k}$. In terms of product specification is as the critical sign considered the multiaxiál width, where the quality character was elected the dimension $1,25 \mathrm{~m}^{ \pm 0,02} \mathrm{~m}$. The process of normality was evaluated by histogram. By statistical For regulation of the stapling process, the Shewhart control chart will be used for average and range ( $\bar{X}$, $R)$.

Averages and ranges are plotted into control charts.

Points are linked by lines to visualise the groups and trends.

Average of process:

$$
\overline{\bar{X}}=\frac{1}{k} \sum_{i=1}^{k} \overline{X_{i}}
$$

where: $i-1,2, \ldots, k$ - sequential number of subgroup for $i=1,2 \ldots k$ and for $j=1,2 \ldots n$ where $\operatorname{MAX}\left(X_{i j}\right)$ and $\operatorname{MIN}\left(X_{i j}\right)$ are maximum and minimum value measured in the $i$-th subgroup

\section{Average range:}

$$
\bar{R}=\frac{1}{k} \sum_{i=1}^{k} R_{i}
$$

where: $R_{i} X_{i}$ - ranges and averages in the $i$-th subgroups $(i=1,2, \ldots k)$.

\section{Calculation of control limits:}

\section{Upper and lower control limits for range and} average:

$$
\begin{aligned}
U C L_{R} & =D_{4} \cdot \bar{R} \\
L C L_{R} & =\underline{D_{3}} \cdot \bar{R} \\
U C L_{\bar{X}} & =\underline{\underline{X}}+A_{2} \cdot \bar{R} \\
L C L_{\bar{X}} & =\bar{X}-A_{2} \cdot \bar{R}
\end{aligned}
$$

where $D_{4}, D_{3}$ and $A_{2}$ are constants of control limits; they change depending on subgroup size from 2 to 25 , in our case the values $D_{3}=0,000, D_{4}=2,282, A_{2}$ $=0,7298$ conform to the size $n=4$.

The process capability indexes

Process capability index $C_{p}$

$$
C_{p}=\frac{U S L-L S L}{6 . \hat{\sigma}}=\frac{T}{6 . \hat{\sigma}}
$$

Corrected process capability index ${ }_{C p k}$

$$
\begin{aligned}
C_{P K} & =\frac{U S L-\overline{\bar{X}}}{3 . \hat{\sigma}} \\
C_{P K} & =\frac{\overline{\bar{X}}-L S L}{3 . \hat{\sigma}}
\end{aligned}
$$


Where: USL, LSL - upper and lower specification limits

$\mathrm{T}$ - tolerance of attribute

$\hat{\sigma}$ - estimation of process standard deviation There is a condition: $C_{p} \geq 1,33$ and $C_{p k} \geq 1,33$ (where is accepted the lower of $\mathrm{C}_{\mathrm{pk}}$ value) (HRUBEC J., KRCHNÁK P. 2014).

\section{Results and discussion}

In the stapling of material layers process by production of product "multiaxiál" values for 25 subgroups were measured. 100 measured values of dimension multiaxiál width are provided in Table 1 . Measured characteristics $\bar{X}$ and $R$ plotted onto the control charts. The central limits and upper and lower central limits were also plotted onto the control charts.

For $(\bar{X}, R)$ control charts these control limits are valid:

$$
\begin{array}{ll}
\mathrm{UCL}_{\mathrm{X}}=1,2573 & \mathrm{UCL}_{\mathrm{R}}=0,0178 \\
\mathrm{LCL}_{\mathrm{X}}=1,2459 & \mathrm{LCL}_{\mathrm{R}}=\text { not defined } \\
\mathrm{CL}_{\mathrm{X}}=1,25157 & \mathrm{CL}_{\mathrm{R}}=0,0,00788
\end{array}
$$

The final measurement average, i.e. the process ability to hold the target value $\mathrm{T}=1,25 \mathrm{~m}$ is well above the required limit. The central limits have not been exceeded. On the basis of these results, as can be seen in Figure 2 - Control chart for range $R$ and in Figure 3 - Control chart for average $\bar{X}$, we can consider the process as stable. Subsequently we approach to process capability indexes $C_{p}$ a $C_{p k}$ calculation.

Obtained values : $\mathbf{C}_{\mathbf{p}}=\mathbf{1 , 6 8} \quad \mathbf{C}_{\mathbf{p k}}=\mathbf{1 , 5 5}$

Based on process capability evaluation we can consider: values $C_{p}=1,68$ and $C_{p k}=1,55$ are higher than 1,33 point, the stapling of material layers process by producing of product "multiaxiál" is in current state sustainable and it is possible to

\begin{tabular}{|c|c|c|c|c|c|c|c|}
\hline $\begin{array}{l}\text { Nr. of } \\
\text { selection }\end{array}$ & Time of & Measure & lues, mm & & & $\overline{\boldsymbol{y}}$ & $R$ \\
\hline 1 & $7: 00$ & 1,25 & 1,246 & 1,254 & 1,25 & 1,25 & 0,008 \\
\hline 2 & $7: 15$ & 1,258 & 1,251 & 1,25 & 1,259 & 1,2545 & 0,009 \\
\hline 3 & 7:30 & 1,247 & 1,255 & 1,253 & 1,255 & 1,2525 & 0,008 \\
\hline 4 & $7: 45$ & 1.252 & 1,256 & 1.247 & 1.248 & 1.25075 & 0,009 \\
\hline 5 & 8.00 & 1,248 & 1,251 & 1,25 & 1,25 & 1,24975 & 0,003 \\
\hline 6 & $8: 15$ & 1.258 & 1,253 & 1.256 & 1.255 & 1.2555 & 0.005 \\
\hline 7 & $8: 30$ & 1,25 & 1,245 & 1,254 & 1,247 & 1,249 & 0,009 \\
\hline 8 & $8: 45$ & 1,255 & 1,251 & 1,249 & 1,253 & 1,252 & 0,006 \\
\hline 9 & $9: 00$ & 1,257 & 1,248 & 1,258 & 1,254 & 1,25425 & 0,01 \\
\hline 10 & $9: 15$ & 1,247 & 1,253 & 1,25 & 1,248 & 1,2495 & 0,006 \\
\hline 11 & $9: 30$ & 1.251 & 1.257 & 1.248 & 1,25 & 1.2515 & 0.009 \\
\hline 12 & $9: 45$ & 1,25 & 1,253 & 1,247 & 1,257 & 1,25175 & 0,01 \\
\hline 13 & $10: 00$ & 1,256 & 1.246 & 1.255 & 1.247 & 1.251 & 0,01 \\
\hline 14 & 10:15 & 1,251 & 1.25 & 1.25 & 1.248 & 1.24975 & 0,003 \\
\hline 15 & $10: 30$ & 1,258 & 1,254 & 1,254 & 1,257 & 1,25575 & 0,004 \\
\hline 16 & 10.45 & 1,25 & 1,259 & 1.251 & 1,258 & 1,2545 & 0,009 \\
\hline 17 & $11: 00$ & 1,244 & 1,25 & 1,254 & 1,25 & 1,2495 & 0,01 \\
\hline 18 & $11: 15$ & 1.254 & 1.256 & 1.247 & 1.259 & 1.254 & 0.012 \\
\hline 19 & $11: 30$ & 1,251 & 1,248 & 1,254 & 1,251 & 1,251 & 0,006 \\
\hline 20 & $11: 45$ & 1,256 & 1,253 & 1,245 & 1,257 & 1,25275 & 0,012 \\
\hline 21 & 12.00 & 1,252 & 1,249 & 1,248 & 1,255 & 1,251 & 0,007 \\
\hline 22 & $12: 15$ & 1,253 & 1,247 & 1,257 & 1,247 & 1,251 & 0,01 \\
\hline 23 & 12.30 & 1,248 & 1,253 & 1.249 & 1,253 & 1,25075 & 0,005 \\
\hline 24 & 12.45 & 1,246 & 1,256 & 1,254 & 1,248 & 1,251 & 0,01 \\
\hline \multirow[t]{2}{*}{25} & $13: 00$ & 1,249 & 1.246 & 1.246 & 1.244 & 1.24625 & 0,005 \\
\hline & & & & & & $\bar{X}=1,25157$ & $\bar{R}=0,00788$ \\
\hline
\end{tabular}
continue in its further improvement.

Table 1. Measured values of dimension multiaxiál width

Source: KLOKNER, P. 2011 


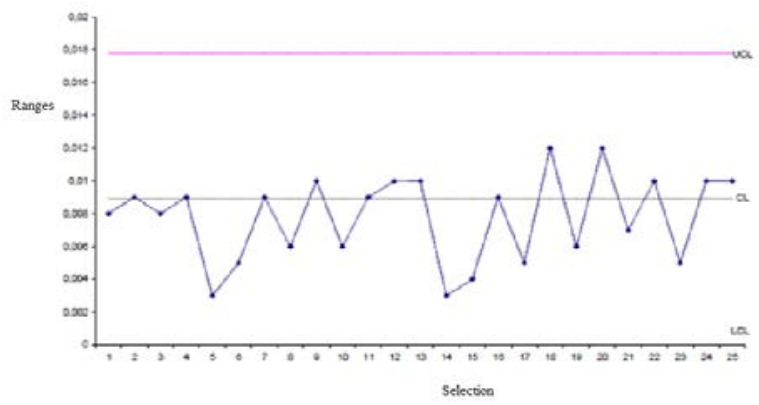

Fig. 2 Control chart for range $R$

Source: KLOKNER, P. 2011

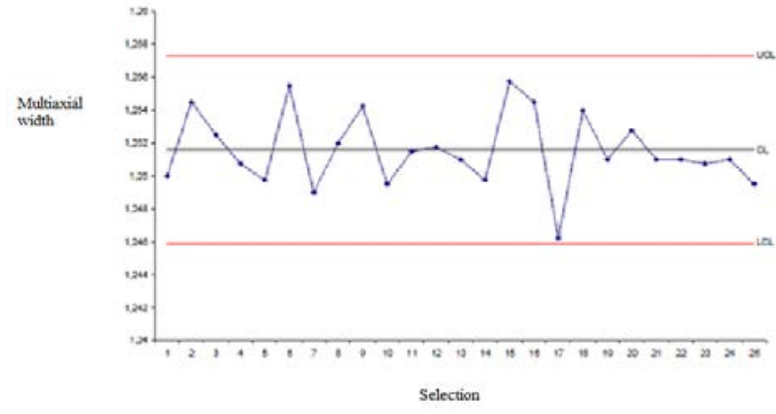

Fig. 3 Control chart for average $\bar{X}$

Source: KLOKNER, P. 2011

\section{Conclusion}

The methods of statistical process control and evaluation of stapling of material layers process capability verify an ability of the process to meet the defined requirements of product quality. The results of process capability $C_{p}=1,68$ and $C_{p k}=1,55$ is evidence that the process is able to permanently provide products complying with the tolerance limits. Control charts are suitable graphic form for probabilistic hypotheses testing. On the basis of the data thus obtained we admit the capability indexes calculation and the process capability evaluation. This information is a signal for the company to improve quality and is evidence for the customer about stable production conditions.

\section{References}

1. HRUBEC, J.: Riadenie kvality. Nitra: SPU v Nitre, 2001. s.203. ISBN 80-7137-849-6

2. HRUBEC, J. KRCHNÁK, P. LESTYÁNSZKA, K.: Inžinierstvo kvality produkcie. 1. Vyd., Vydavatel'stvo SPU v Nitre, Nitra, 2014, 166 s. ISBN 978-80-552-1174-9

3. HRUBEC J., VIRČÍKOVÁ, E: Integrovaný manažérsky systém. Nitra: SPU v Nitre, 2009. s.543. ISBN 97880-552-0231-0

4. KuČEROVÁ, M. - LESTYÁNSZKA, K.: Štatistické metódy kontroly kvality. 1. Vyd., Trnava: AlumniPress MTF STU, 2011, 150 s. ISBN 978-808096-146-6

5. KLOKNER, P.: Analýza štatistickej regulácie procesov $v$ tkáčovni a sledovanie spôsobilosti výrobného zariadenia LIBA v DIPEX, spol. s r.o.. Bakalárska práca. MTF STU so sídlom v Trnave, 2011. 